\title{
GEOINFORMACIJSKA PODPORA PRI DOLOČANJU PRIMERNE LOKACIJE ZA POSTAVITEV LESNOPREDELOVALNEGA CENTRA V OBČINI ILIRSKA BISTRICA
}

\author{
Ajda Kafol Stojanović*, dipl. geografinja, dr. Blaž Repe** \\ *Viška cesta 49a, SI- 1000 Ljubljana \\ ** Oddelek za geografijo, Filozofska fakulteta Univerze v Ljubljani \\ Aškerčeva 2, SI-I000 Ljubljana \\ e-mail:kafol.ajda@gmail.com, blaz.repe@ff.uni-lj.si
}

Izvirni znanstveni članek

COBISS 1.01

DOI: $10.4312 /$ dela.45.5.83-99

\section{Izvleček}

$\mathrm{V}$ prispevku je opisan primer uporabe geoinformacijske podpore odločanju pri iskanju primerne lokacije za postavitev lesnopredelovalnega centra. Analiza je bila omejena na občino Ilirska Bistrica, ki izkazuje velik potencial za rabo lesne biomase. Odločitev smo podprli z ovrednotenimi dejavniki in omejitvami, ki vplivajo na primernost lokacije. Rezultat večkriterijskega vrednotenja je zemljevid primernosti za postavitev lesnopredelovalnega centra in predstavitev najprimernejše, terensko preverjene lokacije v neposredni bližini Ilirske Bistrice.

Ključne besede: lesnopredelovalni center, občina Ilirska Bistrica, geoinformatika, geoinformacijska podpora odločanju, Slovenija

\section{GIS DECISION SUPPORT OF FINDING SUITABLE LOCATION FOR WOOD PROCESSING CENTRE INTHE MUNICIPALITY OF ILIRSKA BISTRICA}

\begin{abstract}
The paper presents how GIS decision support methods were applied in order to find the most suitable location for the wood processing centre. Analysis was focused on the Municipality of Ilirska Bistrica, where a big potential for the wood biomass use was identified. Decision was supported with weighted factors and constraints that influence on the suitability of location. The result of the multi-criteria evaluation is a suitability map for the location of wood processing centre. According to the field work the most suitable location was selected in the vicinity of the town Ilirska Bistrica.
\end{abstract}

Key words: wood processing centre, Municipality of Ilirska Bistrica, geoinformatics, GIS decision support, Slovenia 


\section{UVOD}

Lesna biomasa je na državni ravni prepoznana kot pomemben domači obnovljivi vir, uporaben za gradnjo in proizvodnjo izdelkov, toplote ter električne energije. Butala in Turk (1998) med lesno biomaso uvrščata gozdne ostanke, ostanke pri industrijski predelavi lesa, namensko pridelan les za energetske namene in kemično neobdelan les. Posamezne oblike lesne biomase so lahko pripravljene v gozdu ali kasneje v lesnopredelovalnih obratih $\mathrm{v}$ obliki polen, sekancev, peletov ali briketov (Klun in sod., 2009). Potreba po lesnopredelovalnem centru je bila na državni ravni utemeljena v treh načrtih oziroma programih. Cilj Nacionalnega gozdnega programa je povečanje rabe lesa kot energenta in materiala (Resolucija o ..., 2007). Glavni cilji Akcijskega načrta »Les je lep« za povečanje konkurenčnosti gozdno-lesne verige do leta 2020 so: ustvariti trg za lesne proizvode in storitve, nova delovna mesta $\mathrm{v}$ lesnopredelovalni industriji ter povečanje proizvodnje primarne energije iz lesne biomase za 30 \% (Les je lep, 2012). Akcijski načrt za obnovljive vire energije (2010) predvideva nadomeščanje kurilnega olja z lesno biomaso in sočasno proizvodnjo električne energije in toplote iz lesne biomase. Lesnopredelovalni center z dejavnostmi skladiščenja lesa, predelavo lesa v lesna goriva, mizarsko dejavnostjo ter sočasno proizvodnjo električne energije in toplote predstavlja ukrep k doseganju zadanih ciljev, saj pomeni korak k obuditvi lesnopredelovalne industrije, ustvarja trg za lesne proizvode in storitve, nova delovna mesta ter povečuje proizvodnjo primarne energije iz lesne biomase.

$\mathrm{V}$ prispevku je predstavljena raziskava, v kateri je primerna lokacija za postavitev lesnopredelovalnega centra izbrana s pomočjo geoinformacijske metode večkriterijskega vrednotenja. Kot vzorčni primer za umestitev lesnopredelovalnega centra smo izbrali občino Ilirska Bistrica (Kafol Stojanović, 2015): pri tem smo upoštevali potencial za rabo lesne biomase in pripravljenost lokalnih oblasti za uporabo lesne biomase. Odločitev o primerni lokaciji za postavitev lesnopredelovalnega centra je temeljila na analizi 14 ovrednotenih prostorskih kriterijev, podprtih s strokovno literaturo ali zakonodajo. Rezultat analize je zemljevid primernosti za postavitev lesnopredelovalnega centra in predstavitev najprimernejše ter terensko preverjene lokacije.

\section{METODE DELA}

V prvem delu smo pregledali razpoložljivo literaturo o možnostih uporabe lesne biomase in primere dobrih praks lesnih centrov iz Slovenije in Avstrije. Sledil je pregled državnih akcijskih načrtov in programov glede lesne biomase ter oblikovanje koncepta lesnopredelovalnega centra in njegovih dejavnosti.

V drugem delu smo na podlagi podatkov o značilnostih gozdov (Zavod za gozdove Slovenije), 12 regionalnih razvojnih programov za obdobje 2014-2020 in lokalnih energetskih konceptov za nadaljnjo analizo izbrali občino Ilirska Bistrica, saj izkazuje velik potencial za uporabo lesne biomase.

$\mathrm{V}$ tretjem delu smo na podlagi zakonodaje, strokovne literature in smernic za postavitev objektov izbrali prostorske kriterije, ki pomembno vplivajo na primernost lokacije za postavitev lesnopredelovalnega centra. Metoda večkriterijskega enociljnega vrednotenja 
Slika 1: Shematski prikaz poteka dela.

Figure 1: Schematic workflow presentation.

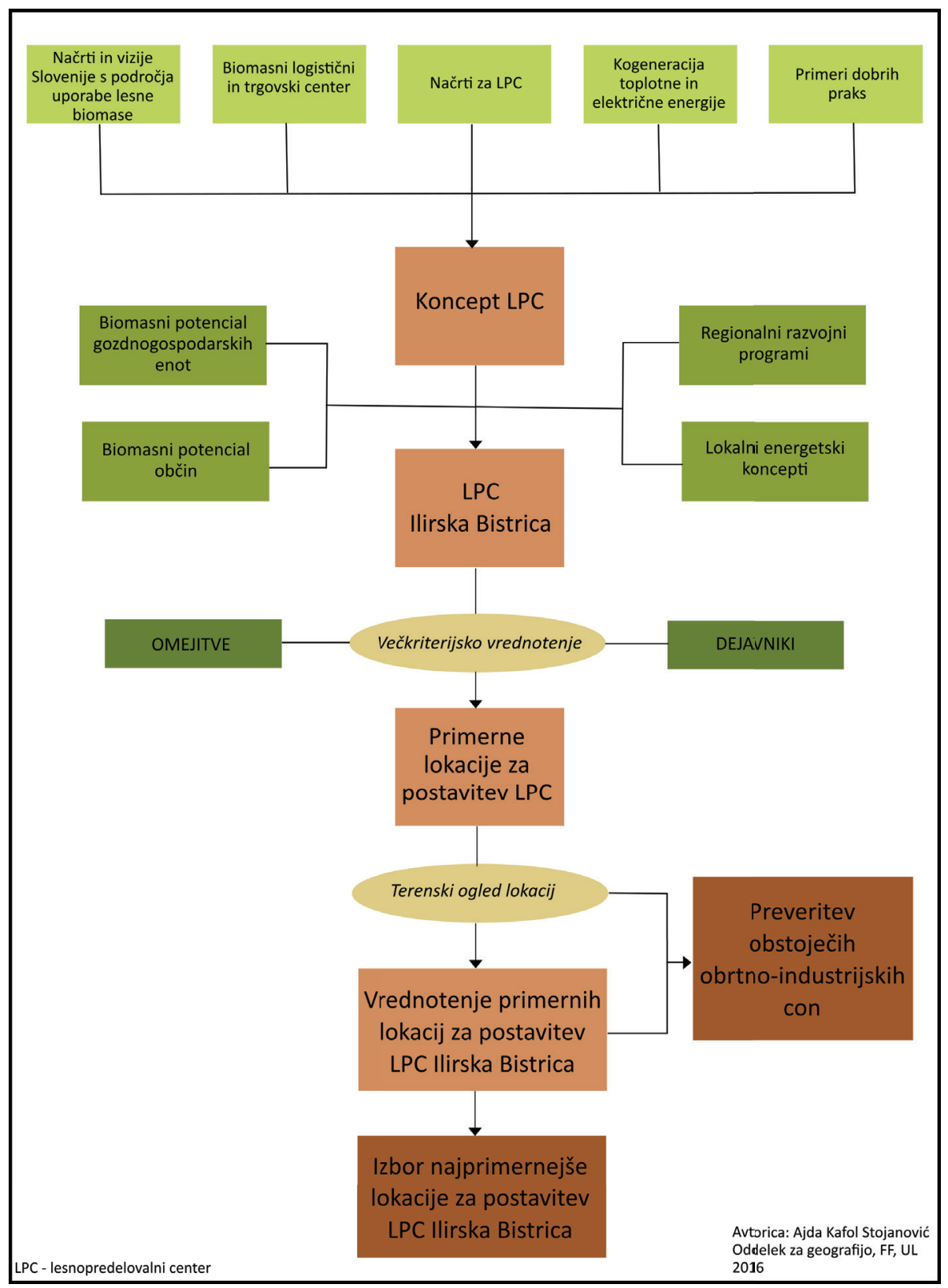


prostorskih kriterijev je pripeljala do končnega zemljevida primernih površin za postavitev lesnopredelovalnega centra.

V zadnjem delu smo na podlagi vrednotenja izbrali pet lokacij z veliko primernostjo za postavitev lesnopredelovalnega centra. Vse smo si ogledali na terenu, jih ovrednotili na podlagi dejanskega stanja in nato določili najprimernejšo. Izbrali smo lokacijo v neposredni bližini Ilirske Bistrice. Na koncu smo z vidika uporabljenih prostorskih kriterijev za postavitev lesnopredelovalnega centra preverili tudi primernost dveh obstoječih industrijskih con v občini Ilirska Bistrica (Kafol Stojanović, 2015).

\section{I Izbor preučevanega območja (občine)}

Izbor občine, v kateri smo z geoinformacijsko podporo odločanju iskali primerne lokacije za postavitev lesnopredelovalnega centra, je potekal v več korakih. Na začetku smo s pregledom 12 regionalnih razvojnih programov za obdobje 2014-2020 izbrali občine, ki spadajo v razvojne regije (Gorenjska, Koroška, Savinjska, Spodnjeposavska, Jugovzhodna Slovenija in Primorsko-notranjska), kjer se zavedajo prednosti uporabe lesne biomase za različne namene in kjer je lesna biomasa opredeljena kot prednostna naloga prihodnjega razvoja. Izmed tako izbranih 94 občin smo s pregledovalnikom ocen potencialov občin za rabo lesne biomase na podlagi devetih kazalcev izbrali občine z najvišjo oceno vseh kazalcev. Uporabljeni kazalci so bili:

- demografsko-socialni (delež zasebne gozdne posesti, površina gozda na prebivalca, delež stanovanj, ki za ogrevanje uporabljajo les kot glavni ali edini vir energije),

- gospodarski (delež gozda, realizacija najvišjega možnega poseka, ocenjen delež lesa, primernega za energetsko rabo) in

- gozdnogospodarski (povprečna velikost gozdne posesti, delež težje dostopnih in manj odprtih gozdov, delež mlajših razvojnih faz gozdov; Sinteza kazalcev, 2015).

Število primernih občin za lokacijo lesnopredelovalnega centra smo ob upoštevanju omenjenih kazalcev zožili na 46. Pomanjkljivost uporabljenih kazalcev je, da ne posredujejo podatkov o količini lesnih ostankov in nekontaminiranega odsluženega lesa, zato smo v naslednjem koraku upoštevali še podatek o količini žagarskih ostankov v lesnopredelovalnih obratih po posameznih občinah. Žagarski ostanki so pomembni za nadaljnjo predelavo lesa v goriva, predvsem pelete in brikete (Butala, Stritih, Turk, 2002). Izračunali smo dodaten kazalec, ki pove, kolikšna je razlika v količini žagarskih ostankov pri predelavi hlodovine ob realizaciji možnega poseka in trenutni realizaciji poseka. V šestih občinah je bila razlika v količini žagarskih ostankov večja od $5000 \mathrm{~m}^{3}$, kar predstavlja neizkoriščen potencial za uporabo (Grum, 2015). V zadnjem koraku smo za občine Gorenja vas - Poljane, Ilirska Bistrica, Kranjska Gora, Gorje, Črnomelj in Ribnica ob pregledu lokalnih energetskih konceptov dobili vpogled $\mathrm{v}$ trenutno stanje na področju energetike in načrte za prihodnji razvoj. Na podlagi teh izsledkov in vključitvi velikosti občine kot dodatnega kazalca smo kot območje preučevanja izbrali občino Ilirska Bistrica. Predstavljeno vrednotenje je pokazalo, da sodi občina Ilirska Bistrica med občine z visokim potencialom za uporabo lesne biomase (Energetski koncept ..., 2008). 
Po površini je občina Ilirska Bistrica druga največja slovenska občina, saj meri približno 480 km². Občina zajema dele Snežniške planote, Podgrajskega podolja, Jelšanskega podolja, Brkinov, južnega dela Zgornje Pivke in dolino reke Reke. Občina Ilirska Bistrica je skupaj z občinami Pivka, Loška dolina, Bloke, Cerknica in Postojna del Primorsko-notranjske razvojne regije, vendar sodeluje tudi v Južno Primorski regiji, kjer ima status opazovalke. Preko občine poteka najkrajša cestna povezava med Postojno in Reko na Hrvaškem ter železniška povezava proti Reki. V občini je leta 2015 živelo 13.667 prebivalcev, zadnjih 20 let je bil naravni prirastek negativen (Prebivalstvo po občinah, 2016). Gozd pokriva 68 \% površine občine. Javne stavbe za ogrevanje navkljub velikemu potencialu ne uporabljajo lesne biomase, temveč kurilno olje. Glede na velik delež individualnih stanovanj (59 \%), ki za ogrevanje uporabljajo lesno biomaso, je potrebno poskrbeti, da se le-ta učinkovito uporablja. V energetskem konceptu občine navajajo, da je potrebno stare kotle z nizkim izkoristkom nujno nadomestiti z novimi. Smiselna je tudi povezava več uporabnikov za učinkovito skupno ogrevanje na lesno biomaso. Ker nobena izmed javnih stavb za ogrevanje ne uporablja lesne biomase, je potrebno razmisliti o zamenjavi kurilnega olja z lesno biomaso (Energetski koncept ..., 2008).

Cilji upravljanja z gozdom, določeni v Regionalnem razvojnem programu Primorsko-notranjske regije za obdobje 2014-2020 (2014), so:

- spodbuditi gospodarno ravnanje z gozdom,

- povečati ekonomsko učinkovitost gospodarjenja z gozdom,

- povečati rabo in trženje lesa in lesne biomase,

- spodbuditi interesno združevanje lastnikov gozdov in njihovo aktivno delovanje.

Na podlagi ugotovljenega je mogoče umestitev lesnopredelovalnega centra v občino Ilirska Bistrica oceniti kot smiselno in upravičeno razvojno potezo. V centru se bo uporabljal lokalni in obnovljivi vir energije, obenem se bosta proizvajali električna in toplotna energija, vpeljan bo skupen sistem ogrevanja za zdajšnje individualne porabnike, odprta bodo tudi nova delovna mesta, ki jih v občini primanjkuje.

\subsection{Izbor prostorskih kriterijev in večkriterijsko vrednotenje}

Sistemi za podporo prostorskemu odločanju so orodja, ki pomagajo pri reševanju prostorskih problemov in sprejemanju prostorskih odločitev (Sugumaran, Degroote, 2011). $\mathrm{V}$ raziskavi smo za iskanje najprimernejših lokacij za postavitev lesnopredelovalnega centra uporabili programsko opremo ArcMap 10.2.2 in Idrisi Selva 17.0. Cilj raziskave smo dosegli z metodo večkriterijskega enociljnega vrednotenja. S pomočjo strokovne literature, zakonodaje in smernic za postavitev objektov smo določili 14 prostorskih kriterijev, ki smo jih razdelili na omejitve ter dejavnike. Slednji povedo, kakšna je primernost določene alternative (Eastman, 2006). Pred vrednotenjem smo dejavnike in omejitve standardizirali na merski lestvici od 0 (najmanjša primernost) do 255 (največja primernost) ter obtežili na podlagi Saatyjeve metode (1996).

$\mathrm{V}$ raziskavi smo kot prostorske omejitve za postavitev lesnopredelovalnega centra uporabili vodovarstvena in poplavna območja, območja varovalnih gozdov in gozdnih 
Slika 2: Graf obtežitve dejavnikov.

Figure 2: Weighted factors.

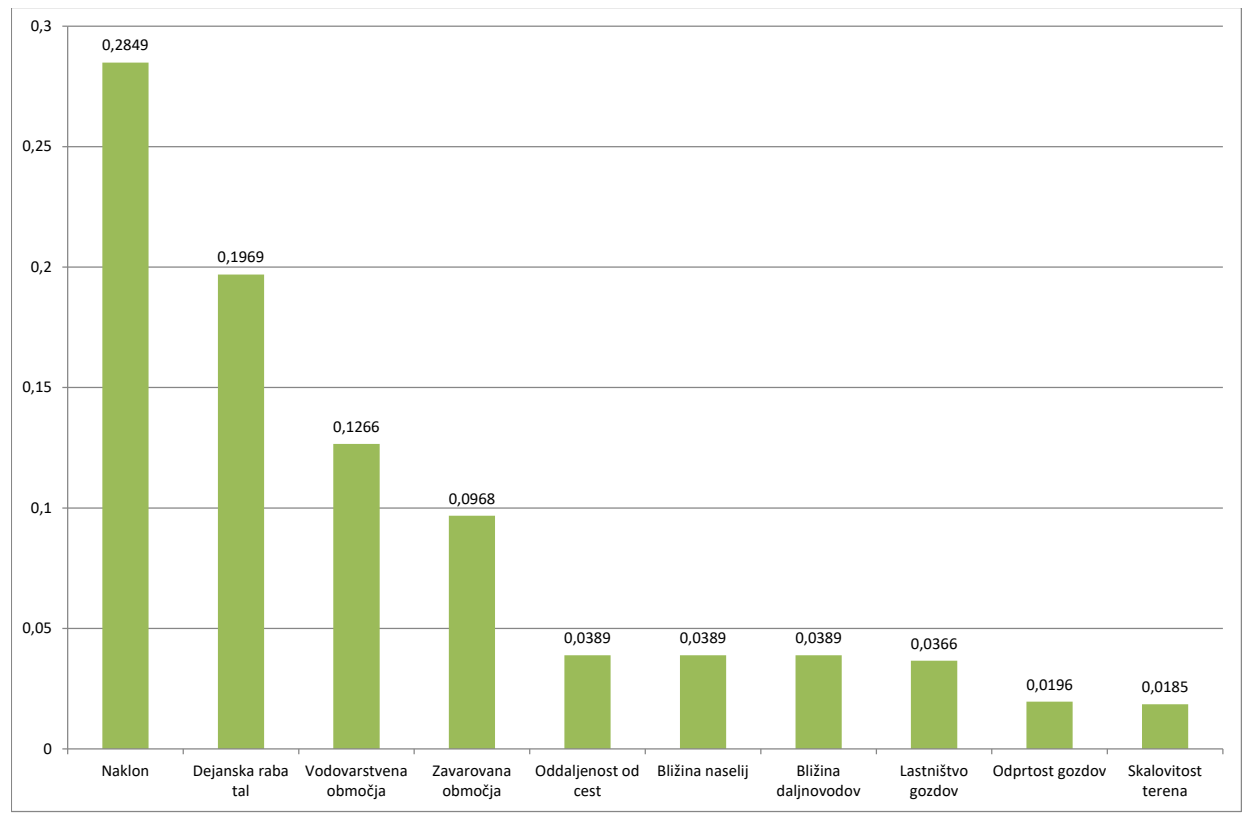

rezervatov ter prometno in energetsko infrastrukturo, saj na njih gradnja ni možna. Uporabljeni prostorski dejavniki, ki povečujejo oziroma zmanjšujejo primernost določene lokacije, so bili: naklon in skalovitost površja, raba tal, zavarovana območja, odprtost gozdov, bližina prometne in energetske infrastrukture, bližina naselij, lastništvo gozdov in velikost gozdnih posesti. Naklon ter dejanska raba tal sta bila z utežjo določena kot najpomembnejša dejavnika. Poseg v prostor na območjih z neprimernim naklonom je težaven oziroma nemogoč in predvsem zelo zamuden. Postavitev lesnopredelovalnega centra na območja kmetijske rabe ni ustrezna, saj morata biti prostorsko in varstveno načrtovanje povezana, upoštevati in spoštovati je potrebno različne prostorske interese. Z ekspertno oceno smo uteži z nižjo vrednostjo določili dejavnikom, ki nimajo ključnega vpliva na postavitev lesnopredelovalnega centra, a so kljub temu pomembni in vplivajo na obseg in strošek postavitve takega centra.

Skalovitost površja je dejavnik, ki nam pove, kolikšen del površine gozdnega odseka pokrivajo površinsko vidne skale (Ciglič in sod., 2011). Majhna skalovitost označuje manj kot $10 \%$ skalnatega površja, srednja med 11 in $30 \%$ površja, velika pa nad $30 \%$ skalnatega površja. $Z$ vidika dela $v$ gozdu je neugodna površina $\mathrm{z}$ več kot $50 \%$ skalovitostjo (Normativi gozdnih del, 2010). Z uporabniško določeno funkcijo, pri kateri smo na podlagi strokovne literature sami določili razrede, smo opisali dejavnik skalovitosti površja in mu pripisali vrednosti med 0 in 255 . 
Slika 3: Skalovitost površja v občini Ilirska Bistrica.

Figure 3: Rockiness of terrain in the Municipality of Ilirska Bistrica.

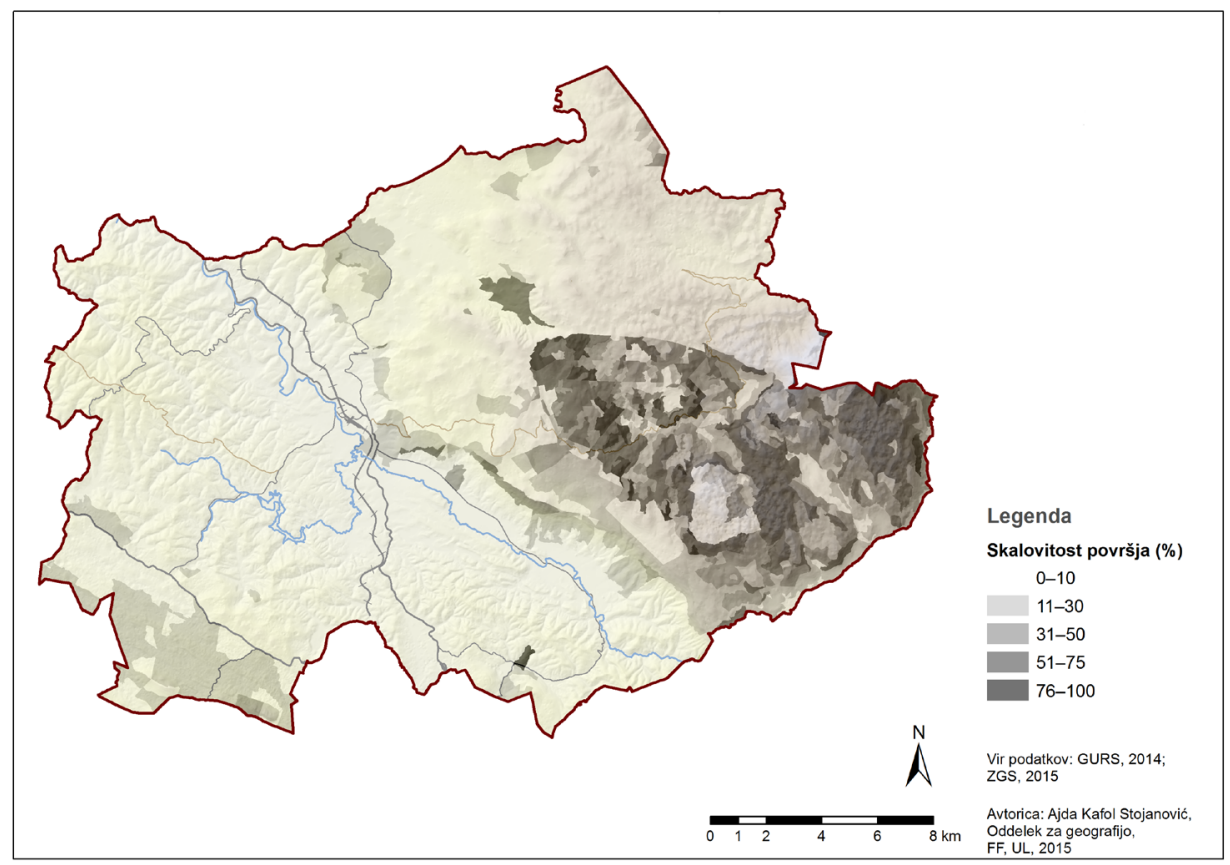

Preglednica 1: Vrednotenje skalovitosti površja.

Table 1: Evaluation of the rockiness of terrain.

\begin{tabular}{|c|c|c|c|}
\hline Tip skalovitosti & Površina & Delež skalovitosti & Vrednotenje \\
\hline Majhna & $349 \mathrm{~km}^{2}$ & pod $10 \%$ & 255 \\
\hline Srednja & $64 \mathrm{~km}^{2}$ & $10-30 \%$ & $255-150$ (linearni upad) \\
\hline \multirow{2}{*}{ Velika } & \multirow{2}{*}{$66 \mathrm{~km}^{2}$} & $30-50 \%$ & $150-50$ (linearni upad) \\
\cline { 3 - 4 } & & $50-60 \%$ & $50-0$ (linearni upad) \\
\cline { 3 - 4 } & & nad $60 \%$ & 0 \\
\hline
\end{tabular}


Slika 4: Primernost za postavitev lesnopredelovalnega centra z vidika skalovitosti površja. Figure 4: Suitability for a wood processing centre according to the rockiness of terrain.

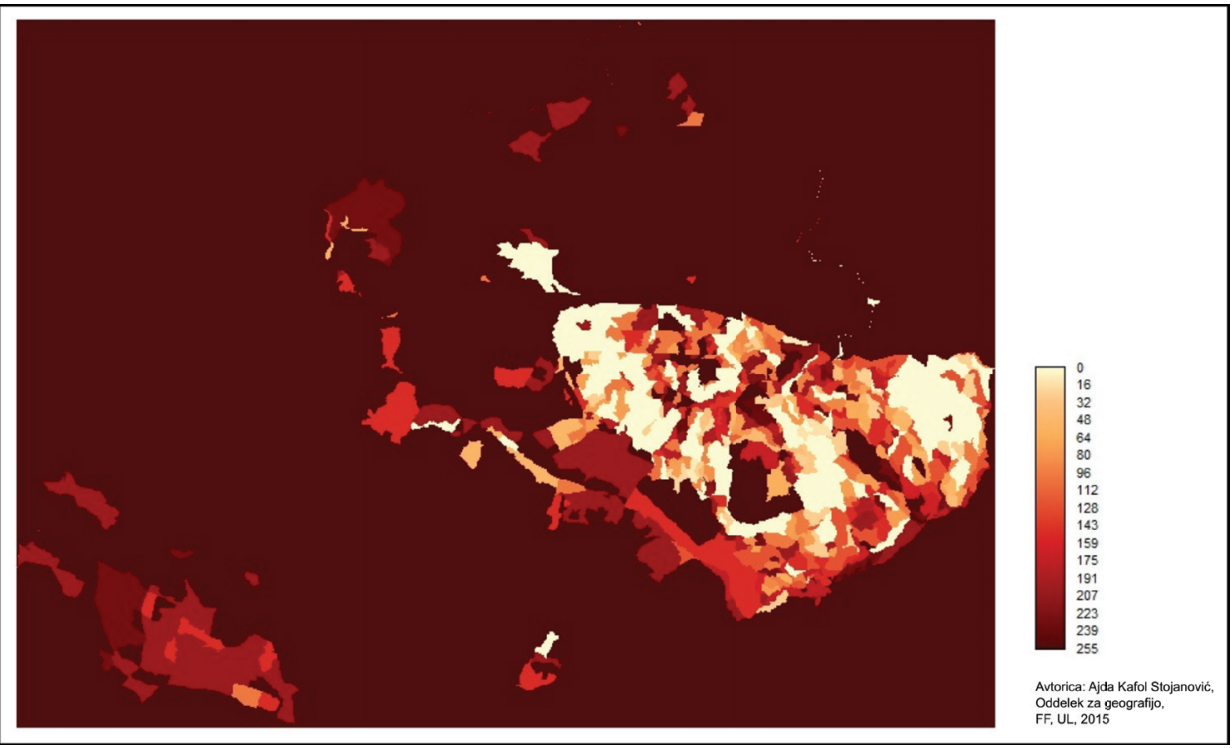

Prometna infrastruktura hkrati nastopa v vlogi omejitve in dejavnika. V Zakonu o cestah (2010) je glede na kategorijo ceste določen varovalni pas, ki predstavlja prostor ob vozišču, kjer je raba prostora omejena. Pri avtocestah znaša varovalni pas $40 \mathrm{~m}$, pri hitrih cestah $35 \mathrm{~m}$, pri glavnih cestah $25 \mathrm{~m}$, pri regionalnih cestah $15 \mathrm{~m}$, pri lokalnih cestah, javnih poteh in zbirnih mestnih cestah pa 4-8 m. V Zakonu o varnosti v železniškem prometu (2013) je 6 oziroma $8 \mathrm{~m}$ od tirov proge določen progovni pas, kjer se ne sme graditi objektov, ki niso nujno potrebni za delovanje železniškega sistema. V stometrskem pasu od progovnega pasu je gradnja objektov pogojno dovoljena, vendar le-ti ne smejo poškodovati ali ovirati proge oziroma zmanjševati nosilnosti površja.

$\mathrm{Z}$ upoštevanjem varovalnih pasov je prometna infrastruktura vrednotena kot omejitev za postavitev lesnopredelovalnega centra. Po drugi strani predstavljajo cestne in železniške povezave dejavnik, ki s svojo bližino spodbuja umestitev lesnopredelovalnega centra (slika 6). Bližina cestnih in železniških povezav izboljša logistiko dostave, odvoza surovin in izdelkov ter zniža ceno prevoza. Prometna infrastruktura tako predstavlja oba tipa kriterijev (dejavnik in omejitev). Na podoben način predstavlja tudi energetska infrastruktura z možnostjo priključitve na omrežje dejavnik za postavitev lesnopredelovalnega centra, z upoštevanjem njenih varovalnih pasov pa omejitev.

Na predstavljeni način smo vrednotili vse izbrane prostorske kriterije; nato smo izvedli metodo obtežene linearne kombinacije, katere rezultat je zemljevid primernosti površin za postavitev lesnopredelovalnega centra v občini Ilirska Bistrica. Nadalje smo z vpeljavo dodatnih kriterijev iskali sklenjena območja s površino, večjo od 8 ha (tj. 
Slika 5: Prometna infrastruktura v občini Ilirska Bistrica.

Figure 5: Transport infrastructure in the Municipality of Ilirska Bistrica.

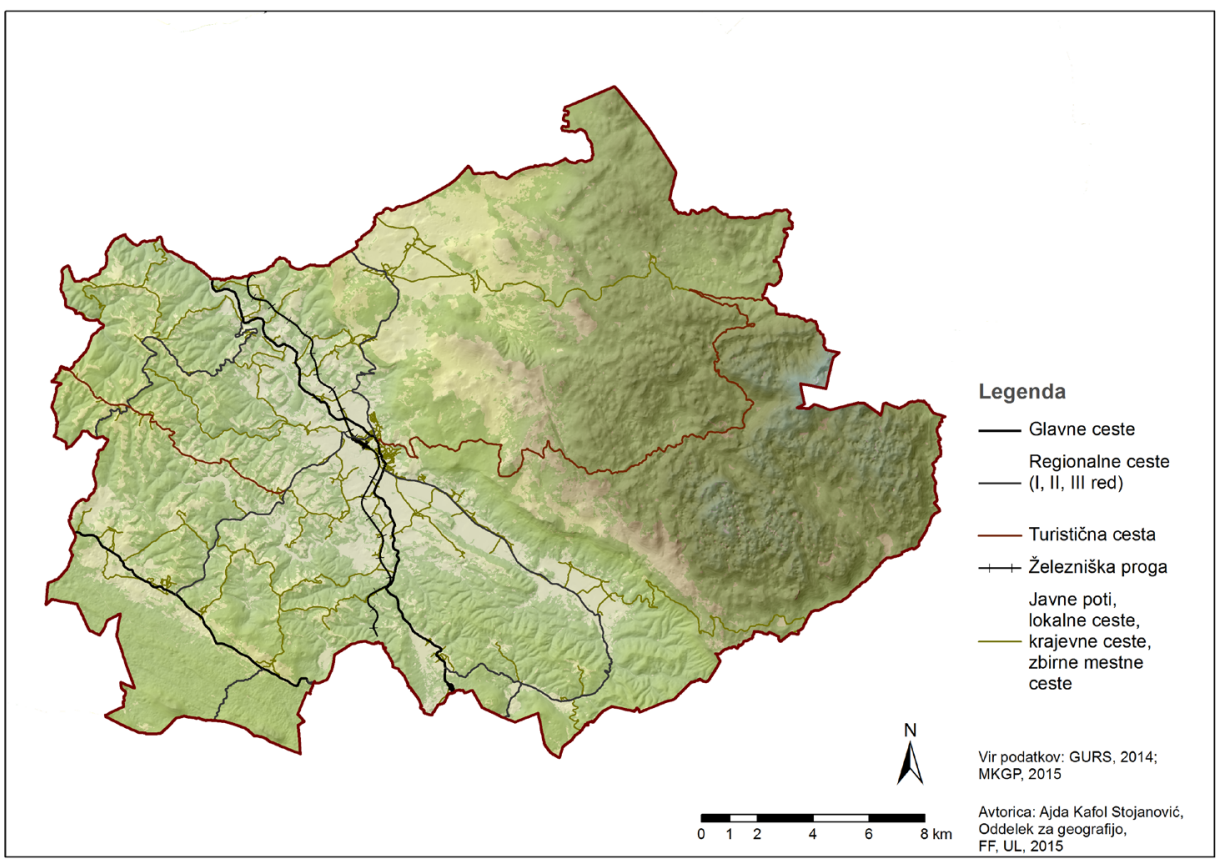

velikost podobnih lesnih centrov, lesnih obratov in biomasnih elektrarn; Krajnc, Premrl, 2010; Vizija 2020, 2013). Pet lokacij, ki so ustrezale vsem kriterijem, smo si ogledali na terenu, jih podrobneje vrednotili in izbrali najprimernejšo lokacijo za postavitev lesnopredelovalnega centra. 
Slika 6: Primernost za postavitev lesnopredelovalnega centra $z$ vidika prometne infrastrukture (slika 6 b) in prometna infrastruktura kot omejitev (slika 6 a).

Figure 6: Suitability for a wood processing centre in terms of transport infrastructure (Figure 6 b) and transport infrastructure as a constraint (Figure 6 a).

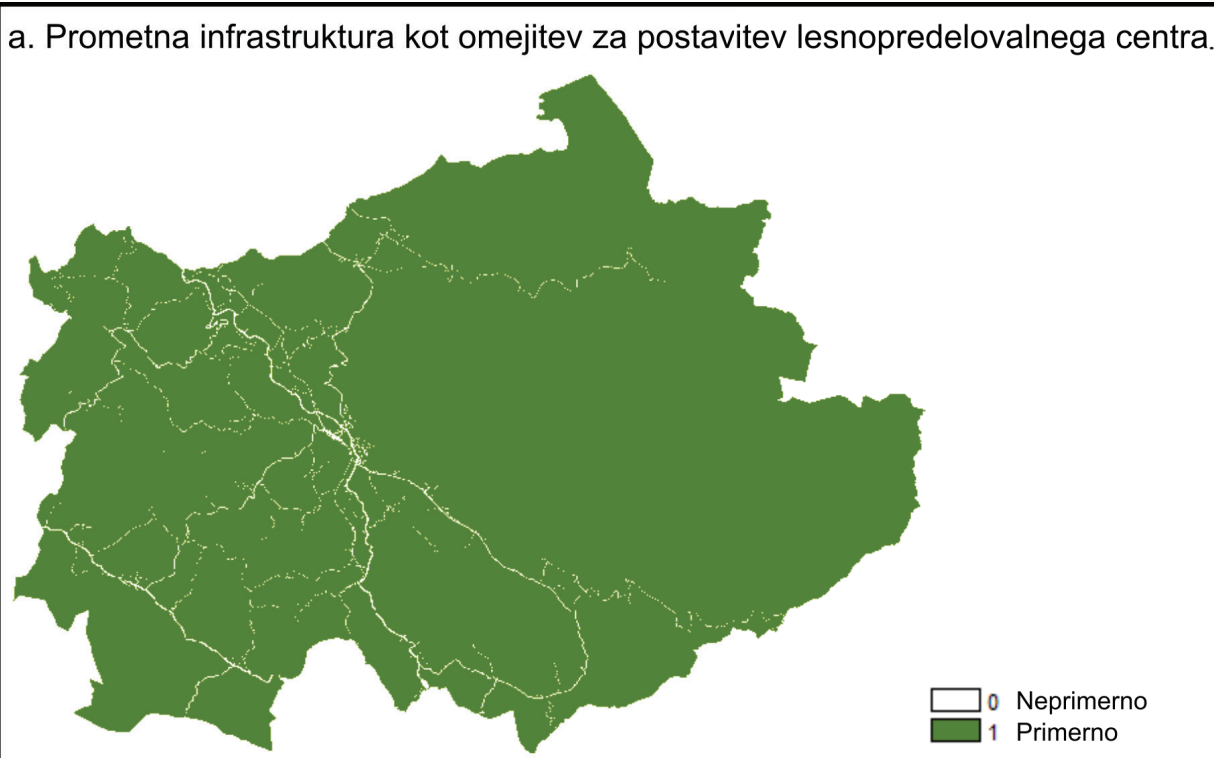

b. Prometna infrastruktura kot dejavnik, ki povečuje primernost lokacije za postavitev lesnopredelovalnega centra.

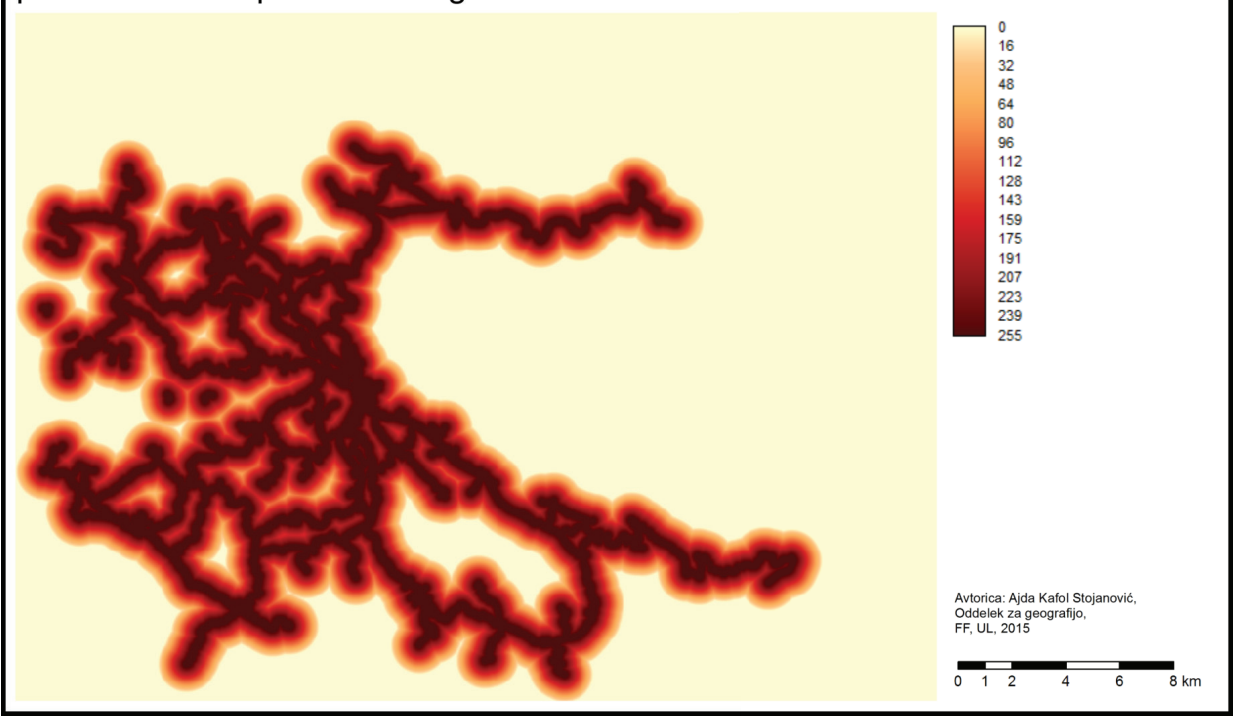




\section{REZULTATI}

Zemljevid primernosti za postavitev lesnopredelovalnega centra $\mathrm{z}$ belimi lisami prikazuje lokacije, ki so zaradi omejitev neprimerne za postavitev tovrstnega centra. Najprimernejših lokacij, torej tistih z oceno skupne vrednosti nad 200, je v občini Ilirska Bistrica 605 ha in predstavljajo 1,3 \% površine občine. Gre predvsem za območja ob glavni cestni povezavi s Hrvaško, območja v bližini Knežaka v severovzhodnem delu občine ter območja v dolinah rek Reke in Molje. Velik del tako prepoznanih primernih lokacij ne ustreza kriterijema sklenjenosti in velikosti (vsaj 8 ha).

Slika 7: Zemljevid primernosti za postavitev lesnopredelovalnega centra in pet primernih lokacij.

Figure 7: Map of suitability for the wood processing centre and five suitable locations.

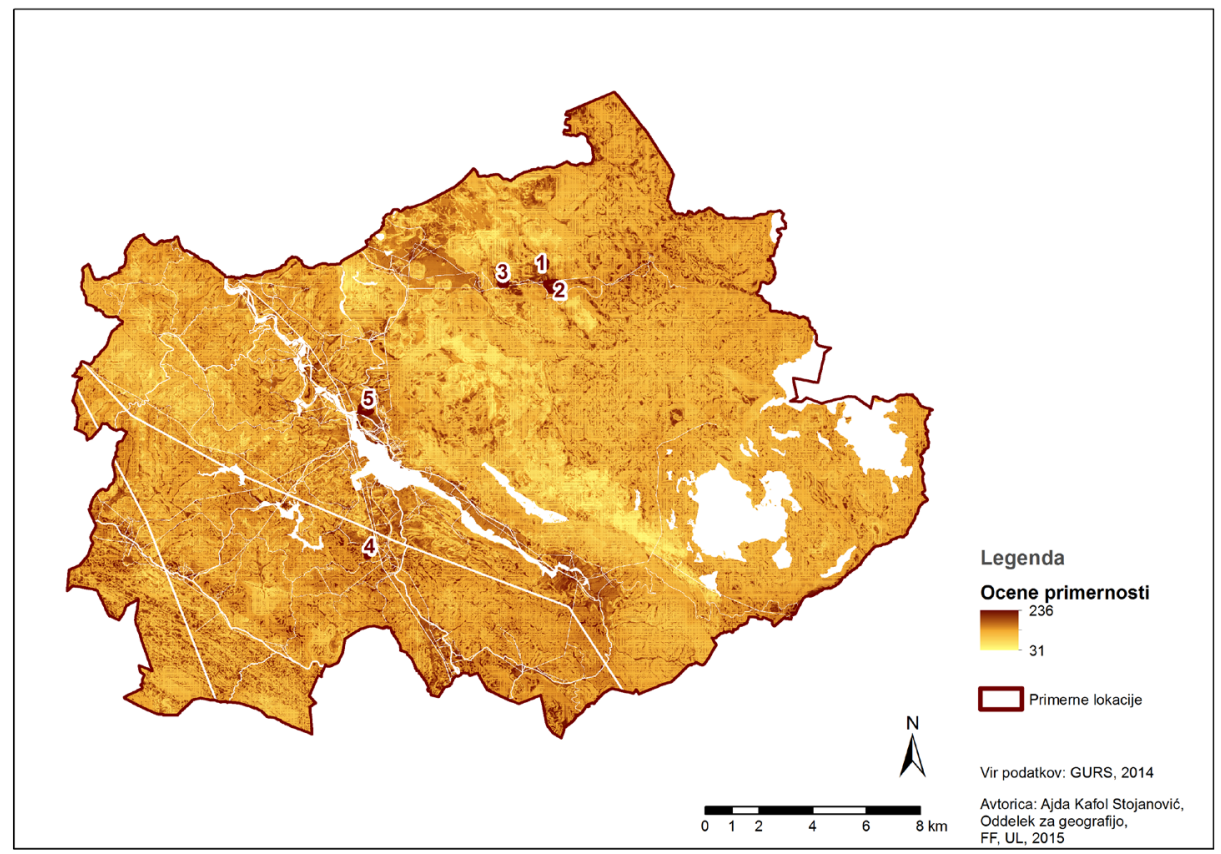

V preglednici 2 so z zaporednimi številkami prikazane najvišje, najnižje in povprečne ocene primernosti posameznih lokacij (slika 7), ki ustrezajo dodatnim kriterijem (sklenjenosti in velikosti). V oceni so upoštevane tudi vrednosti 0 (neugodno), ki skupno povprečno vrednost znižajo. 
Preglednica 2: Vrednosti petih primernih lokacij za postavitev lesnopredelovalnega centra. Table 2: Values of five suitable locations for a wood processing centre.

\begin{tabular}{|c|c|c|c|c|}
\hline Lokacija & $\begin{array}{c}\text { Velikost } \\
\text { lokacije }\end{array}$ & $\begin{array}{c}\text { Najnižja dosežena } \\
\text { ocena primernosti }\end{array}$ & $\begin{array}{c}\text { Najvišja dosežena } \\
\text { ocena primernosti }\end{array}$ & $\begin{array}{c}\text { Povprečna ocena } \\
\text { primernosti }\end{array}$ \\
\hline 1 & $11 \mathrm{ha}$ & 119 & 205 & 167 \\
\hline 2 & $13,5 \mathrm{ha}$ & 106 & 228 & 185 \\
\hline 3 & $10,8 \mathrm{ha}$ & 114 & 225 & 184 \\
\hline 4 & $8,3 \mathrm{ha}$ & 100 & 215 & 172 \\
\hline 5 & $10,6 \mathrm{ha}$ & 109 & 216 & 172 \\
\hline
\end{tabular}

Prve tri lokacije, ki se nahajajo ob Knežaku, imajo podobne lastnosti. Najvišja ocena primernosti na lestvici od 0 do 255 , ki jo je dosegla ena izmed teh treh lokacij, znaša 228. Povprečne ocene primernosti prvih treh lokacij se gibljejo med 167 in 185 , lokacije so primerne velikosti, med 10,8 in 13,5 ha, prav tako je primeren njihov povprečni naklon, ki znaša manj od $3^{\circ}$. Po mnenju Pogačnika (1999) in Vinka (1983; cv. Ciglič, 2008) je za gradnjo najbolj primerno zemljišče s povprečnim naklonom pod $2,9^{\circ}$. Dejanska raba na lokacijah je gozd, prav tako je namenska raba prostora gozd oziroma na manjšem delu druga kmetijska zemljišča (Občina Ilirska Bistrica, 2015). Z vidika infrastrukturne opremljenosti so lokacije dostopne po asfaltirani lokalni cesti, možna je priključitev na elektroenergetsko omrežje $20 \mathrm{kV}$. Z vidika odprtosti gozdov, skalovitosti površja in velikosti gozdnih posesti so primerne vse lokacije. Negativne lastnosti vseh treh lokacij so vključenost v Naturo 2000 in prisotnost ekološko pomembnega območja Snežnik-Pivka, slabe cestne povezave ter prevelika oddaljenost od večjih naselij, saj bližnje vasi ne predstavljajo dovolj velikega trga za proizvode in storitve lesnopredelovalnega centra.

Lokacija južno od naselja Ilirska Bistrica, velika 8,3 ha in na sliki 7 označena s številko 4, je bila v analizi izbrana kot ena izmed primernih lokacij za postavitev lesnopredelovalnega centra. Povprečni naklon je primeren, saj znaša pod $3^{\circ}$, dejanska raba je kombinacija travnika, pašnika in gozda, medtem ko je namenska raba označena kot druga kmetijska zemljišča (Občina Ilirska Bistrica, 2015). Lokacija je dobro infrastrukturno opremljena, saj je v bližini cesta, ki se navezuje na glavno cestno povezavo med Ilirsko Bistrico in Hrvaško, poleg tega pa so v bližini tudi daljnovodi različnih napetosti. Na lokaciji ni nobene izmed kategorij varovanja narave, lokacija ni poplavno ogrožena, skalovitost površja je zanemarljiva, odprtost gozdov je dovolj velika. Negativna lastnost lokacije je le majhna velikost gozdne posesti, ki znaša 1,3 ha na lastnika.

Po terenskem ogledu se je kot primerna lokacija za postavitev lesnopredelovalnega centra izkazala lokacija št. 5 (slika 7) na severnem robu Ilirske Bistrice, tj. ob obstoječi obrtno-industrijski coni. V primeru postavitve lesnopredelovalnega centra v bližino obrtno-industrijske cone bi prišlo do prostorskega zgoščevanja podobnih dejavnosti in razširitev že obstoječe, komunalno opremljene obrtno-industrijske cone.

Glavni prednosti te lokacije sta bližina večjega naselja in bližina komunalno opremljene obrtno-industrijske cone. Ugodni so tudi ostali prostorski kriteriji, kot so ravno, neskalovito in poplavno varno površje, odprtost gozdov, bližina več cestnih in železniških 
Slika 8: Primerna lokacija za postavitev lesnopredelovalnega centra v bližini obrtno-industrijske cone.

Figure 8: Suitable location for the wood processing centre near the industrial zone.

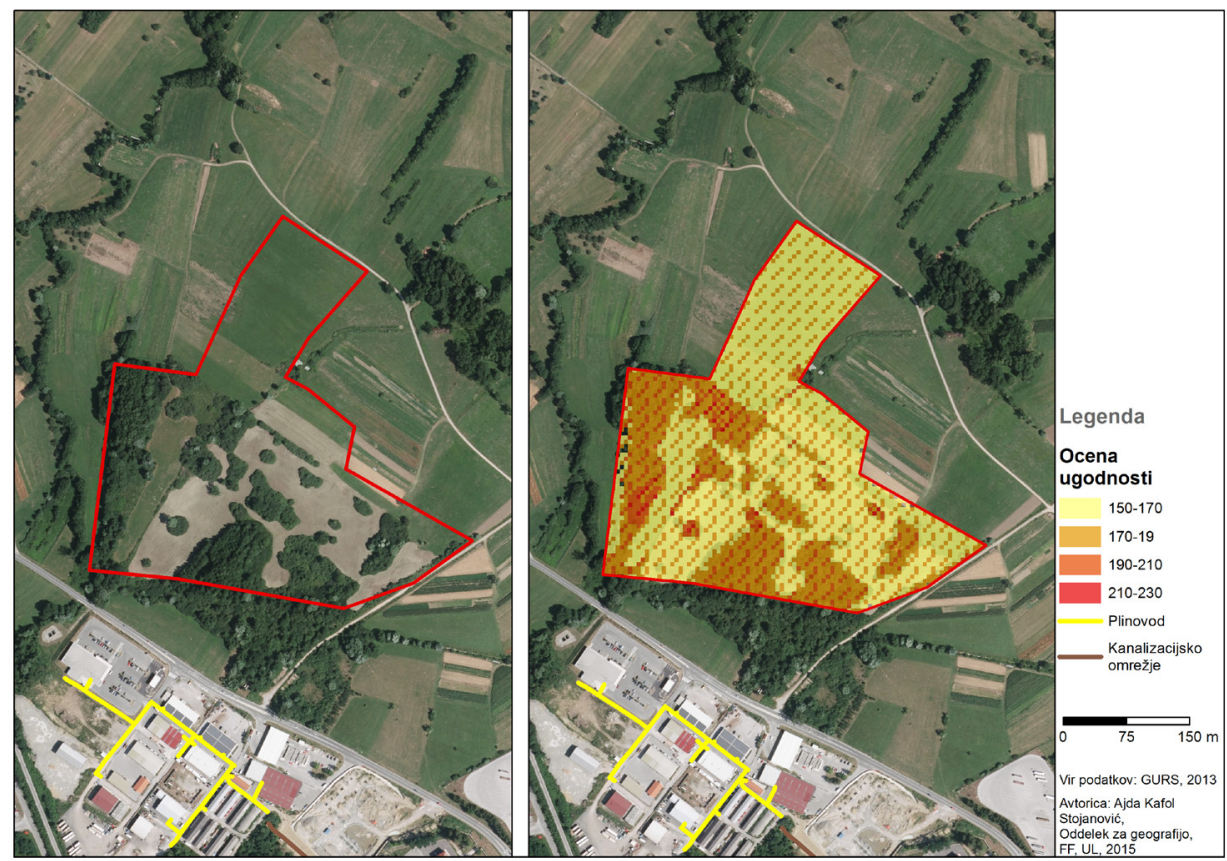

povezav ter bližina elektroenergetskega omrežja različnih napetosti. Negativni lastnosti lokacije sta prisotnost ekološko pomembnega območja doline reke Reke in povprečna vrednost ocene 172, ki je za 20 vrednosti nižja od lokacij v bližini Knežaka. Kljub temu ima lokacija več terensko preverjenih prednosti in je bila posledično predlagana kot najprimernejša lokacija za postavitev lesnopredelovalnega centra.

Preverili smo primernost dveh obstoječih industrijskih con v občini Ilirska Bistrica za postavitev lesnopredelovalnega centra ali podobnih industrijskih objektov.

Izkazalo se je, da je zaradi poplavne ogroženosti kar $63 \%$ obstoječe industrijske cone Ilirska Bistrica popolnoma neprimerne (vrednost 0) za postavitev lesnopredelovalnega centra. Verjetnost katastrofalnih poplav ob reki Reki vpliva na nizko povprečno vrednost primernosti, ki znaša zgolj 61. Druga večja industrijska cona, ki se nahaja v občini Ilirska Bistrica, je Industrijska cona Plama, med naseljema Hrušica in Podgrad v jugovzhodnem delu občine. Povprečna vrednost primernosti v tej coni znaša 145, 4 \% površin pa je neprimernih za postavitev lesnopredelovalnega centra ali podobnih objektov. Edina večja slabost cone je večji naklon površja v primerjavi z naklonom v industrijski coni Ilirska Bistrica, vendar zaradi možnih predhodnih gradbenih posegov to ne predstavlja večje ovire. 
Slika 9: Območje industrijskih con Plama in Ilirska Bistrica.

Figure 9: Location of the industrial zones Plama and Ilirska Bistrica.

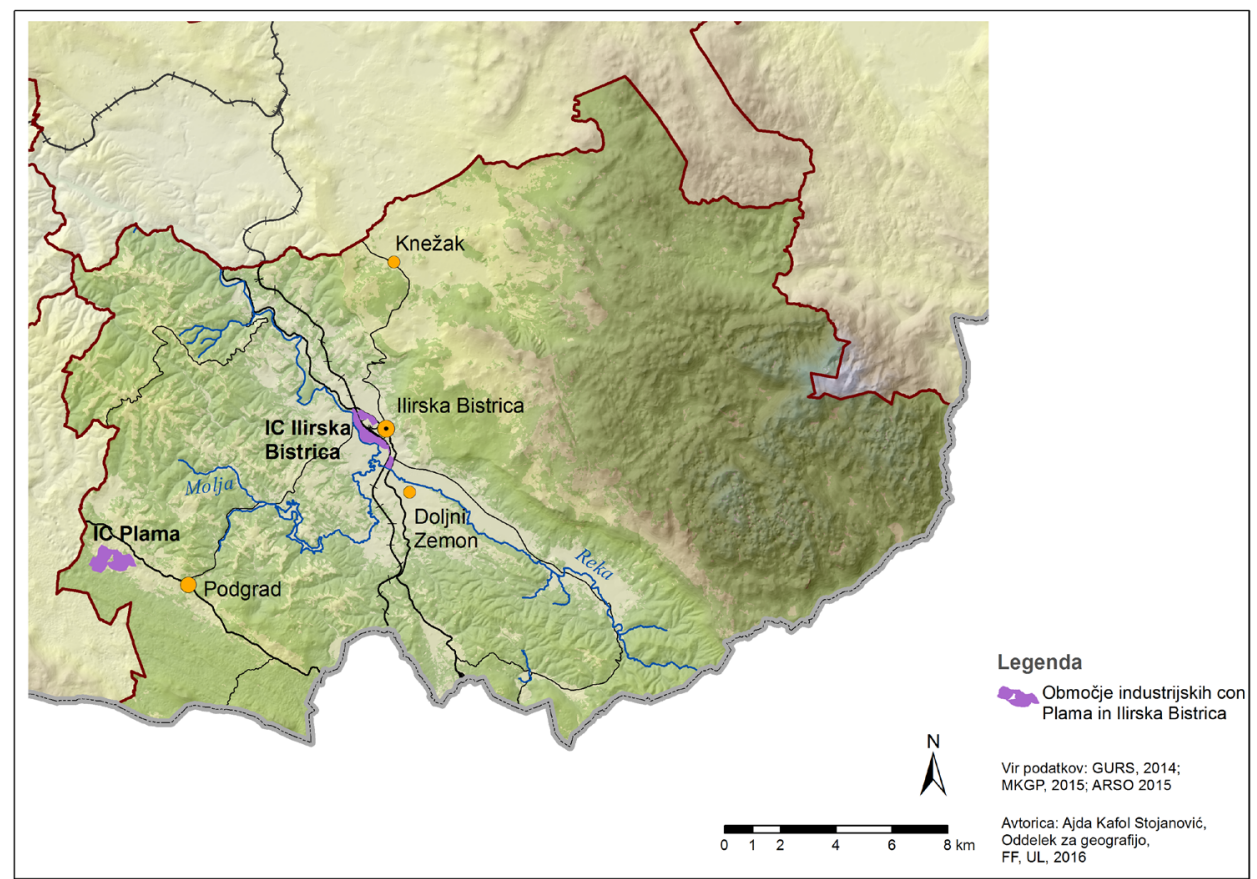

\section{SKLEP}

Pri umeščanju objektov v prostor je potrebno izhajati iz potencialov na eni in potreb na drugi strani. Potrebno je načrtovati trajnostno, upoštevati krajevne značilnosti in tudi omejitve okolja. V prvem delu smo dokazali primernost slovenskih pokrajin za uporabo lesne biomase in prikazali ustreznost metode za iskanje občin oziroma drugih prostorskih enot, ki imajo potencial za uporabo lesne biomase. V drugem delu se je metoda večkriterijskega vrednotenja izkazala kot primerna pri iskanju lokacije za postavitev lesnopredelovalnega centra ali sorodnih lesnih industrijskih obratov. Lokacija v bližini obstoječe obrtno-industrijske cone Ilirska Bistrica, izbrana kot primerna za postavitev lesnopredelovalnega centra, ima pred ostalimi lokacijami glavni prednosti, tj. bližino Ilirske Bistrice in obstoječe obrtno-industrijske cone. Zaokroževanje naselij, zgoščevanje sorodnih dejavnosti, varovanje kmetijskih zemljišč in preprečitev razpršene gradnje so imeli pri izbiri lokacije pomembno vlogo. Omeniti velja, da so bile številne prednosti lokacije ugotovljene s terenskim ogledom, ki je pomemben del raziskave in smiselno dopolni računalniško izvedene analize. Podatki namreč ne zajamejo celotne pokrajinske pestrosti bodisi zaradi njihove nedostopnosti, slabše natančnosti ali zastarelosti.

Pridobljeni rezultati so v največji meri odvisni od izbire vhodnih podatkov, torej prostorskih kriterijev, njihove interpretacije in obtežitve. K boljšim rezultatom bi pripomogla 
uporaba podatkov o nosilnosti in stabilnosti površja, vodovodnem in kanalizacijskem omrežju itd. Podatek o vodovodnem in kanalizacijskem omrežju smo uporabili v zadnjem delu, tj. pri vrednotenju primernosti posameznih, z analizo določenih lokacij. Enako velja za podatek o namenski rabi zemljišč, ki smo ga uporabili pri vrednotenju, saj nam $\mathrm{v}$ času izvedbe analize ni bil na voljo. $\mathrm{V}$ prihodnjih analizah bi bilo smiselno upoštevati tudi lastništvo zemljǐš in podatek o degradiranih površinah, ki bi nosile veliko vlogo pri umestitvi lesnopredelovalnega centra, vendar vsi ti podatki v času analize niso bili na voljo. Končni rezultat je odvisen tudi od interpretacije in obtežitve prostorskih kriterijev. Interpretacija prostorskih kriterijev je bila narejena na podlagi državnih zakonov, prostorskih dokumentov in smernic za gradnjo. Uporabljeno metodo večkriterijskega vrednotenja ocenjujemo kot ustrezno pri podpori prostorskim odločitvam v zvezi z umestitvijo podobnih objektov v prostor, saj je pred začetkom načrtovanja izbira lokacije ključnega pomena. $\mathrm{V}$ skladu $\mathrm{z}$ državnimi vizijami in cilji regionalnih razvojnih programov glede lesne biomase bi bila postavitev lesnopredelovalnega centra upravičena v številnih slovenskih občinah. Predstavljeni pristop, uporabljen na primeru občine Ilirske Bistrice, ima širši pomen na državni, regionalni ter lokalni ravni in je ocenjen kot primeren za ponovno uporabo.

\section{Literatura in viri}

Akcijski načrt za obnovljive vire energije za obdobje 2010-2020 (AN OVE). 2010. Ljubljana, 134 str.

Butala, V., Stritih, U., Turk, J., 2002. Oplemenitena lesna biomasa - vir za klimatske spremembe in podjetniški izziv. Ljubljana, Konzorcij OPET, 18 str.

Butala, V, Turk, J., 1998. Lesna biomasa - neizkoriščeni domači vir energije. Ljubljana, Univerza v Ljubljani, Fakulteta za strojništvo, Center za energetske in ekološke tehnologije, 20 str.

Ciglič, R., 2008. Večkriterijsko vrednotenje v prostorskem načrtovanju. Geografski vestnik, 80, 1, str. 109-118.

Ciglič, R., Komac, B., Pavšek, M., Zorn, M., 2011. Neodgovorna odgovornost. Ljubljana, ZRC SAZU, 149 str.

Eastman, J. R., 2006. IDRISI Andes Tutorial. Worcester, Clarklabs, Clark University, 284 str. URL: http://gis.fns.uniba.sk/vyuka/DTM_ako_sucast_GIS/Kriging/1/Andes_ Tutorial.pdf (citirano 9. 4. 2015).

Energetski koncept občine Ilirska Bistrica, Končno poročilo. 2008. Ljubljana, Eco Consulting, d. o. o., 145 str.

Grum, A., 2015. Podatki Občine, Excelova preglednica, Zavod za gozdove Slovenije (osebni vir, marec 2015). Ljubljana.

Kafol Stojanović, A. 2015. Geoinformacijska podpora določanja ustrezne lokacije za postavitev lesno predelovalnega centra v občini Ilirska Bistrica. Zaključna seminarska naloga. Ljubljana, Univerza v Ljubljani, Filozofska fakulteta, Oddelek za geografijo, 88 str. 
Klun, J., Krajnc, N., Mihelič, M., Piškur, M., Piškur, B., Premrl, T., Robek, R., Sinjur, I., 2009. Lesna goriva, Drva in sekanci. Ljubljana, Gozdarski inštitut Slovenije, Založba Silva Slovenica, 83 str.

Krajnc, N., Premrl, T., 2010. Biomasni logistični in trgovski centri. Trije koraki do uspešne realizacije projekta. Ljubljana, Gozdarski inštitut Slovenije, Silva Slovenica, $33 \mathrm{str}$.

Les je lep. Akcijski načrt za povečanje konkurenčnosti gozdno-lesne verige v Sloveniji do leta 2020. 2012. Ljubljana, MKO in MGRT, 38 str.

Normativi gozdnih del. 2010. Ljubljana, 46 str. URL: http://www.uradni-list.si/files/RS_2010-098-05089-OB P002-0000.PDF\#!/pdf (citirano 9. 4. 2015).

Občina Ilirska Bistrica, GIS. Osnovna namenska raba. 2015. URL: http:/gis.iobcina.si/ gisapp/Default.aspx?a=ilirskabistrica (citirano 8. 5. 2015).

Pogačnik, A., 1999. Urbanistično planiranje. Ljubljana, Univerza v Ljubljani, Fakulteta za gradbeništvo in geodezijo, 252 str.

Prebivalstvo po občinah. SURS. URL: http://pxweb.stat.si/pxweb/Database/Dem soc/05_prebivalstvo/10_stevilo_preb/20_05C40_prebivalstvo_obcine/20_05C40_ prebivalstvo_obcine.asp (citirano 12.3.2016).

Regionalni razvojni program Primorsko-notranjske regije za obdobje 2014-2020. 2014. Pivka, RRA Notranjsko-kraške regije d.o.o., 123 str. URL: http://www.rra-zk.si/materiali/priloge/slo/rrp-pnr-2014-2020_december-2014_konna.pdf (citirano 15. 3. 2015).

Resolucija o nacionalnem gozdnem programu. 2007. Uradni list RS, 72 str. URL: http:// www.zgs.si/fileadmin/zgs/main/img/PDF/Katalog_IJZ/NGP3.pdf (citirano 5. 4. 2015).

Saaty, T. L., 1996. Decision Making with Dependence and Feedback: The Analytic Network Process. Pittsburgh, Pennsylvania, RWS Publications, 370 str.

Sinteza kazalcev, Zavod za gozdove Slovenije. URL: http:/www.zgs.si/slo/delovna podrocja/lesna_biomasa/potenciali_po_obcinah/sinteza_kazalcev/index.html\#c2669 (citirano 13. 3. 2015).

Sugumaran, R., Degroote, J., 2011. Spatial Decision Support Systems: Principles and Practices. New York, CRC Press, 469 str.

Vizija 2020. Energetska učinkovitost občine Šentrupert. Kako postati energetsko neodvisna lokalna skupnost. 2013. Šentrupert, Javno podjetje energetika Šentrupert, d. o. o., 38 str.

Zakon o cestah. 2010. Uradni list RS. URL: https://www.uradni-list.si/1/content?id=101701 (citirano 10. 4. 2015).

Zakon o varnosti v železniškem prometu (ZVZelP). 2013. Uradni list RS. URL: http:// www.pisrs.si/Pis.web/pregledPredpisa?id=ZAKO4240 (citirano 10. 4. 2015). 


\section{GIS DECISION SUPPORT OF FINDING SUITABLE LOCATION FOR WOOD PROCESSING CENTRE INTHE MUNICIPALITY OF ILIRSKA BISTRICA}

\section{Summary}

Wood is recognized as a strategic, domestic, renewable and natural resource of Slovenia. Due to the wood processing industry decline and the desire for cleaner local energy source, the concept of wood processing centre was created, where energy from wood biomass is produced and local wood products are sold. Such centre has many advantages for residents, i.e. heat and electricity production, reliable local supply of wood fuels, wood products and job opportunities. When locating an object it is necessary to proceed from potentials on one side and needs on the other. It is vital to plan sustainable and to take into account local characteristics and limitations of the environment.

In the first part of our research the suitability of Slovenia for the wood biomass use was analysed and the most suitable municipality from an aspect of high wood biomass potential was eliminated. The main goal of the second part of the research was to find suitable wood processing centre location in the Municipality of Ilirska Bistrica. Factors used in analysis were slope inclination, land use, protected areas, openness of forest, rockiness of terrain, roads, settlements, electrical infrastructure, forest ownership and size of the forest properties. Constraints recognized in analysis were forest reserves, flood areas, water protected areas, roads, railways and electrical infrastructure. The results depend on the input spatial criteria, interpretation and weighing. The interpretation of spatial criteria was made on the basis of state laws, planning documents and guidelines for construction of the wood processing centre. With the help of constraints and factors used in multicriteria evaluation method, the final results of the analysis were given; such as the map of estimated suitability of locations in the Municipality of Ilirska Bistrica, the analysis of five most suitable locations and selection of the most suitable location, which is situated next to the industrial zone Ilirska Bistrica. The main advantages over other suitable locations are closeness of the town Ilirska Bistrica and its existing industrial zone. It is worth mentioning that many advantages of selected location were identified with the field work, which is an important part of the research and complementary to the computerimplemented analysis.

Upgraded multicriteria evaluation method is evaluated as adequate for placement of similar objects. In accordance with national visions and regional development goals regarding wood biomass, the wood processing centre placement would be also justified in other municipalities. The presented analysis could be used again in the case of similar processing or energy objects placement.

(Translated by the authors) 